\title{
下流端条件に対する分岐部の流量配分比の 応答に関する基礎的研究 \\ STUDY ON DISTRIBUTION RATIO IN BIFURCATION OF RESPONSE TO DOWN STREAM BOUNDARY CONDITION
}

\author{
小関博司 ${ }^{1} \cdot$ 星野 剛 ${ }^{2} \cdot$ 安田 浩保 ${ }^{3}$ \\ KOSEKI Hiroshi, HOSHINO Tsuyoshi and YASUDA Hiroyasu \\ 1 学生会員 新潟大学大学院 自然科学研究科（干 950-2181 新潟県新潟市西区五十嵐二の町 8050) \\ 2 学生会員 修 (工学) 新潟大学大学院 自然科学研究科（广 950-2181 新潟県新潟市西区五十嵐二の町 8050) \\ 3 正会員 博 (工学) 新潟大学准教授災害・復興科学研究所（广 950-2181 新潟県新潟市西区五十嵐二の町 8050)
}

\begin{abstract}
Theoretical one-dimensional method, estimating distribution discharge ratio is limited to apply to natural rivers because it is derived from condition with uniform flow in branch channels. Simple numerical model to understand flow characteristics and distribution discharge ratio of dividing flows has not been established even though it is important to understand the characteristics and distribution discharge ratio for flood control. In this paper, the explicit 2D-computed numerical model with square grid apply to compute flow pattern in experiment flume with bifurcation, the computed results agree with measured result of the flume. 2D shallow water model is applicable to dividing flows for obtaining flow characteristics and distribution discharge ratio. The results of numerical experiment with non-uniform flow condition indicates that downstream water level in the branch channels are related to the discharge ratio.
\end{abstract}

Key Words: $\quad$ bifurcation, distribution ratio, two-dimensional analysis, non-uniform flow

\section{1.はじめに}

流路が 2 本以上に分岐する河川では堰や水門が設け られ，下流側流路への流量配分の制御がなされている. 様々な形態の河川を俯瞰すると, 特に治水の観点から みた河道管理においては分岐部の水理の理解は極女て 重要である。しかし, 現状では, 分岐部の水理に関す る既往の研究は極めて少なく，水理特性ばかりか分岐 部の妥当な水理解析の手法さえ十分に示されていない のが現状である.

分岐部に関する既往の研究について, 大きく 3 つに 分類して以下に整理する.

一つ目は流量配分比を推定することを目的とした 1 次元の理論解析に関する研究である. Taylor ${ }^{1)}$ は $\mathrm{T}$ 型 の分岐を対象とした実験結果に基づき主水路と分岐水 路の水深比とフルード数を利用して流量配分比を求め た。嶋ら 2) は分岐後の下流端水深の影響を考慮する必 要がない射流水路における流量配分比を理論的に求め たものの, この理論解は水路幅が広くなるに従い適用 性が低下する性質を内在している。室田 ${ }^{3)}$ は水理実験 を行うとともに，ポテンシャル理論に基づき分岐部の 流線の解とエネルギー方程式からフルード数の関数と なる流量配分比を求める解を導出している. 芦田ら ${ }^{4)}$ は様々な分岐角とそこに種々の上流端流量を与えた実 験を行い, エネルギー方程式から導出された流量配分
比の解の適合性について調べている。室田と芦田らの 流量配分比の解はともに分岐後水路の下流端条件を等 流としているため，実河川における適用範囲は制限さ れる. 長谷川ら 5) は分岐部の一方に堰を有する河道に おける流量配分比を運動量方程式を巧みに立てて求め ることに成功している。これらの 1 次元の理論解析で は, フルード数を唯一の独立変数として流量配分比を 算定しているといえる.

二つ目は河道網の水理を把握することを目的とした 1 次元解析に関する研究である. 伊藤 6) は流速が小さ な低平地の河川網の分合流と湾曲部の損失を理論的に 求めるとともに, 河道網の比較的簡便な解析法を示し た. 岩佐ら 7) は低平地の河道網の解析に適した 1 次元 の数值解析法の提案を行った. 金本ら ${ }^{8)}$ は大規模な河 道網への適用を見越したグラフ理論に基づく 1 次元の 数值解析法を開発した。岩佐らや金本らの研究は分岐 と合流が繰返される河道網の一体的な解析の先駆例で あるが, 河道間の接続が連続条件のみとなるために非 定常性が強い現象への適用性に課題が残る。

三つ目は 2 次元以上の方法により分岐や合流を解析 することを目的とした研究である。福岡ら ${ }^{9)}$, Dinh・ Kimura $\cdot \mathrm{Shimizu}^{10)}$, 後藤・福岡 ${ }^{11)}$ は河道毎に一般座 標により境界適合した格子を作ってそれらを陰的解法 を介して結合する方法を提案している。 また類似の方 法として原ら ${ }^{12)}$ がある。これらの方法はいずれとも河 
道の結合時に新たに境界条件が必要となる。著者ら ${ }^{15)}$ は分岐部と合流部のいずれともを分け隔てをすること なく矩形格子に基づく格子構成により一体的に解析す る方法を提案し, 実河川の平常時から洪水時までの一 連の非定常の水理を良好に再現できることを示した。

このほか, 分岐部では二次流が発達して土砂輸送に 少なからず影響を及ぼすことが知られている ${ }^{13)}$.その 一方で, 現状では，二次流が流況や流量配分比に与え る影響については十分に理解されているとは言えない. 前者の問題に対しては, 3 次元の数值モデルを用いた先 行的な研究 ${ }^{14)}$ が行われている. 後者の問題に対しては, 二次流を無視した平面 2 次元解析モデルの分岐部にお ける適用限界について言及した研究は行われていない.

上記までをまとめると, 河道管理において最も重要 となる不等流における流量配分比の算定方法が現状で は確立されていないことが分かる，本研究では，著者 ら 15)16) が提案している矩形格子による格子構成に基づ く二次流を無視した平面 2 次元解析モデルの分岐部に おける適用性の把握を試みるとともに，さらに流量配 分比が簡便かつ適切に算定される有効な解析手法であ ることを示す，そのためにまず，芦田らにより実施され た室内実験の再現計算を行う。次に, 既往の理論的な 流量配分比算定法 ${ }^{3) 4)}$ は, 分流後を等流としている。 こ のため, 分流後に水門や堰などがある不等流状態のも とで流量配分比の調整がなされている実河川において は，その適用範囲が限定されることが予見される。そ こで, 分岐水路下流端の水位が流量配分比に与える影 響の把握を行うために, 分流後を不等流状態とした数 值実験を行う。さらに, 芦田らの実験水路は分岐後の 水路幅が同一でないため, 分岐角度のみの影響を個別 に把握したとは言い難い。このため, 分岐角度のみが 流量配分比に与える影響を把握することを目的として, 分岐水路の幅が同一の水路形状を用い数值実験を行う.

\section{2. 矩形格子を用いた平面 2 次元解析の妥当性の 検証}

(1) 矩形格子による分岐部の境界適合に関する優位性

一般座標による分岐部の境界適合は前述した陰的解 法を介し河道を接続する方法 9) 10111) のほか，分岐部を 一体的に境界適合する方法がある。しかし, 後者の方 法では格子構成の決定に数ケ月間の試行錯誤を要する ことが報告されている ${ }^{17)}$ 。 また，格子構成が決定した としても, 分岐部では格子の歪曲が大きくなるため打 切り誤差の解消は容易ではない ${ }^{18)}$ 。こ机に対し, 矩形 格子による境界適合では簡便かつ忠実に平面形状を解 析に反映することができ，格子構成が一意に決定する. そのため, 安定した解を得ることが可能となる，以上 のことから, 本解析手法では, 矩形格子による境界適 合を用い解析を行う。

\section{(2) 実験の目的と概要}

矩形格子に基づく平面 2 次元解析による河川の分岐 部の流況の再現性を確認するために, 水路実験の再現

\section{表-1 実験条件 4)}

\begin{tabular}{|c|c|c|c|c|c|}
\hline \multicolumn{2}{|c|}{ CASE } & $\theta_{1}\left({ }^{\circ}\right)$ & $\theta_{2}\left({ }^{\circ}\right)$ & $Q\left(\mathrm{~cm}^{3} / \mathrm{sec}\right)$ & $\kappa$ \\
\hline \multirow{3}{*}{ A } & 1 & \multirow{3}{*}{30} & \multirow{3}{*}{60} & 1000 & 0.250 \\
\hline & 2 & & & 2000 & 0.285 \\
\hline & 3 & & & 3800 & 0.295 \\
\hline \multirow{3}{*}{ B } & 1 & \multirow{3}{*}{60} & \multirow{3}{*}{30} & 1000 & 0.300 \\
\hline & 2 & & & 2000 & 0.335 \\
\hline & 3 & & & 3800 & 0.355 \\
\hline
\end{tabular}

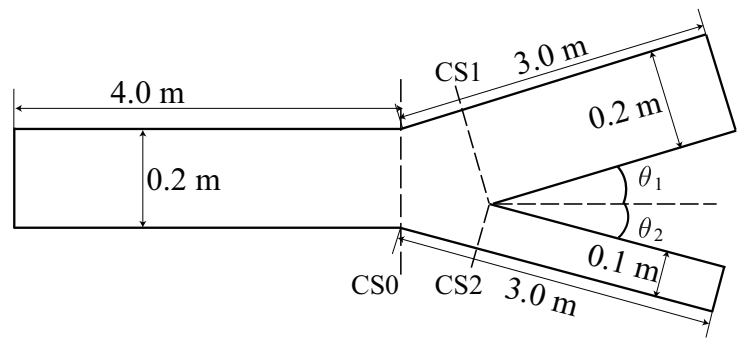

図-1 水路形状 4)

計算を行った。再現計算の対象としたのは, 芦田らに よる水路実験 4) である。この実験は河川の分岐形状と フルード数が分流機構に及ぼす影響の把握を目的とし て, 6 種類の水路形状での水位の測定と流量配分比の算 出を行っている.

水路の形状を図-1 に示す，水路床勾配は 1/1000であ る. 以下, 分岐後の川幅 $0.2 \mathrm{~m}$ の水路を本川と呼び, 川 幅 $0.1 \mathrm{~m}$ の水路を支川と呼ぶ，再現計算を行う分岐角度 $\theta_{1}, \theta_{2}$ と上流端からの流量 $Q$, そして実験結果の支川 への流量配分比 $\kappa$ を表-1 に示した.

\section{(3) 計算格子・支配方程式}

再現計算に用いた格子は一辺 $1 \mathrm{~cm} の$ 正方格子とし， 水路内のみに計算格子を配置している.

支配方程式には，これまでの著者らの研究 ${ }^{16)}$ と同様 の式(1)-(3)を用いた。

$$
\frac{\partial h}{\partial t}+\frac{\partial M}{\partial x}+\frac{\partial N}{\partial y}=0
$$

$$
\begin{array}{r}
\frac{\partial M}{\partial t}+\frac{\partial}{\partial x}\left(\frac{M^{2}}{h}\right)+\frac{\partial}{\partial y}\left(\frac{M N}{h}\right)+g h \frac{\partial H}{\partial x}= \\
-\frac{\tau_{x b}}{\rho}+\frac{\partial}{\partial x}\left(v_{t} \frac{\partial M}{\partial x}\right)+\frac{\partial}{\partial y}\left(v_{t} \frac{\partial M}{\partial y}\right) \\
\frac{\partial N}{\partial t}+\frac{\partial}{\partial x}\left(\frac{M N}{h}\right)+\frac{\partial}{\partial y}\left(\frac{N^{2}}{h}\right)+g h \frac{\partial H}{\partial y}= \\
-\frac{\tau_{y b}}{\rho}+\frac{\partial}{\partial x}\left(v_{t} \frac{\partial N}{\partial x}\right)+\frac{\partial}{\partial y}\left(v_{t} \frac{\partial N}{\partial y}\right) \\
\tau_{x b}=\frac{\rho g n^{2} \sqrt{M^{2}+N^{2}}}{h^{\frac{1}{3}}} \\
\tau_{y b}=\frac{\rho g n^{2} \sqrt{M^{2}+N^{2}}}{h^{\frac{1}{3}}}
\end{array}
$$




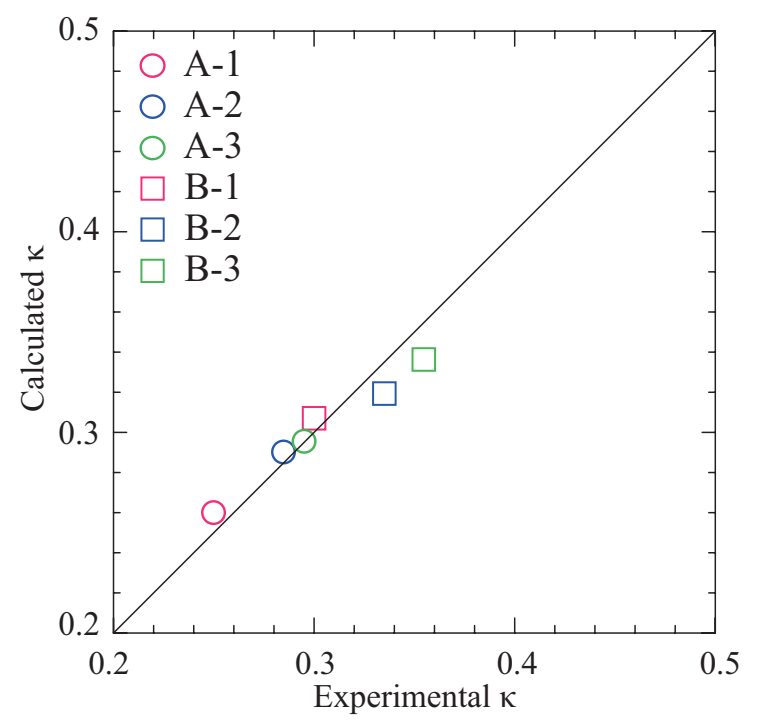

図-2 再現計算結果（流量配分比）

ここで, $M, N$ は $x, y$ 方向の流量フラックス, $t$ は時間 座標， $x, y$ は平面座標， $h$ は水深， $g$ は重力加速度， $H$ は水位, $\tau_{x b}, \tau_{y b}$ は $x, y$ 方向の底面せん断応力, $\rho$ は水 の密度, $v_{t}$ は渦動粘性係数である.

\section{（4）計算条件・境界条件}

粗度係数は, 再現計算の水位と流量配分比が実験結 果と概ね一致するように決定した。計算の上流端の境 界条件には実験での流量と等しくなるように流量フラッ クスを横断方向に一様に与えた。下流端の境界条件に は, 実験結果の流量配分比から求められる等流水深に 基づいた水位を本川，支川にそれぞれ横断方向に一様 に与えた。この条件で流量配分比が時間変化しない状 態（以下，この状態を定常状態とする）に達するまで 計算を行った。

\section{(5) 計算結果}

計算結果から求めら机た支川への流量配分比と，実 験結果の支川への流量配分比を比較したものを図-2 に 示す．計算結果と実験結果の誤差は最大でも5\%となつ たことから，流量配分比の再現性は良好であると判断 出来る.

図-1 に示す分岐の直前と直後の CS0, CS1, CS2 の三 箇所に検査断面を設定し，水路内の横断方向水位分布を 実験結果と比較した。この結果を図-3に示した。横軸 は水路左岸からの距離を水路幅で除した無次元量, 縦軸 は水位となっている，横断方向の水位分布は CSO, CS2 では良好に再現されている。一方で，CS1では実験に おいて観測された右岸側の水位の上昇が再現計算では 見られないものの, 左岸側への水面勾配が再現されて いることは確認出来る.

分岐部における水深分布を図-4に，流線と流速強度 を図-5に示す。これらの図の実験条件は表-1における B-2である，芦田らは，分岐部では急拡によるエネル ギー損失と死水域の発生を指摘している. 分岐直後の 本川の左岸側，支川の右岸側において流線が側壁から

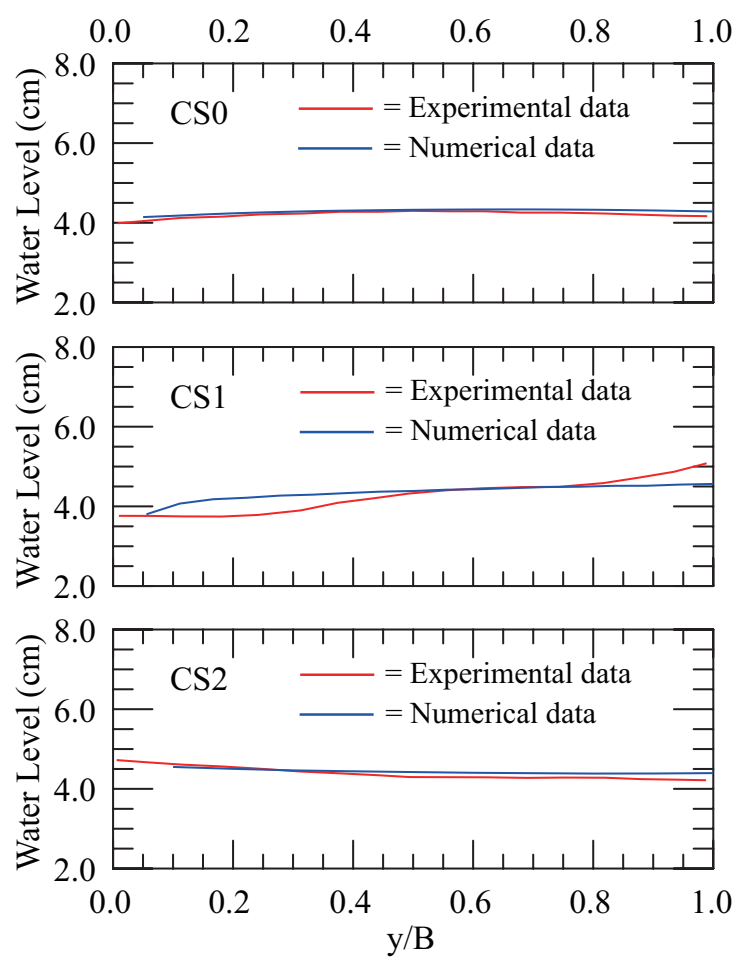

図-3 再現計算結果（横断方向水位分布）

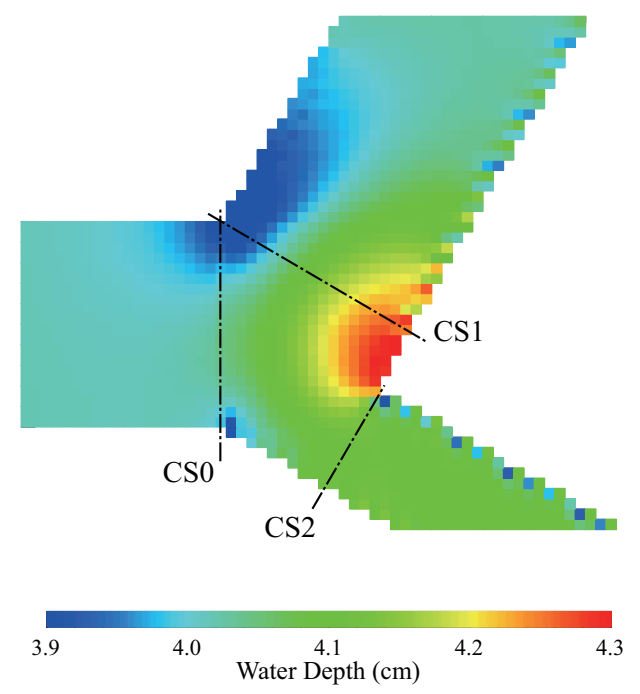

図-4 再現計算結果（水深分布，実験条件：B-2）

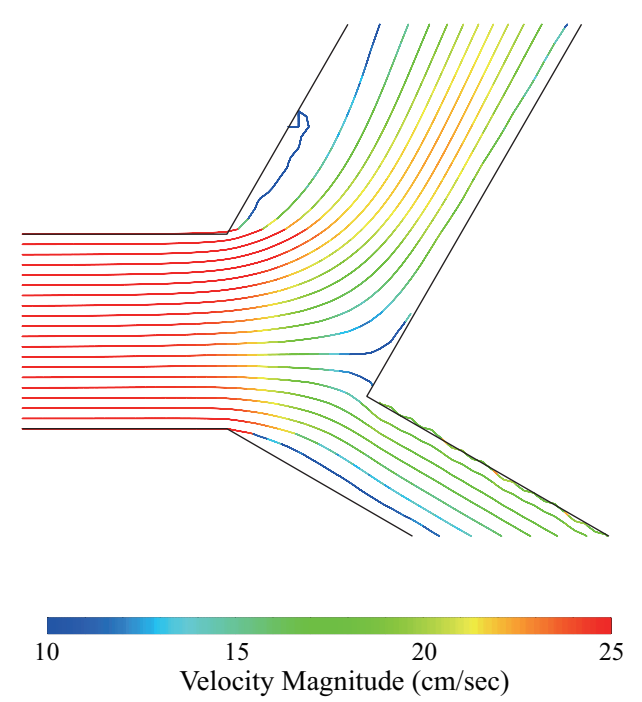

図-5 再現計算結果（流線, 流速強度, 実験条件：B-2) 
離れるような流れが発生しており，図-4ではそれに伴 う水深の減少が見られることから, 彼らが指摘する死 水域を確認出来る. また, 本川右岸側が水衝部となり, 水深の増加および流速の低下が見られる. 以上のこと から, 矩形格子に基づく平面 2 次元解析モデルは, 分 岐部の平面形状を簡便かつ忠実に記述することができ, 流況や流量配分比の把握に適した解析法であると判断 できる。

\section{3. 下流端水深に対する流量配分比の応答の把握 (1) 数値実験の目的と概要}

実河川において，分流後の流れはほとんどが構造物 が設置されるなどして不等流となることが推測出来る. しかし, 過去にこのような条件のもとでの流量配分比 について詳しく調べた研究は見られない。 そこで，分 流後の不等流状態が流量配分比に及ぼす影響を把握す るために, 前章までに妥当性が確認された数值解析モ デルを利用し, 下流端水深を調整して不等流状態とし た条件での数值実験を行う。ここでは, 図-1 の芦田ら の実験水路の形状を用いて数值実験を行った。表-1に おける B の水路形状 $\left(\theta_{1}=60^{\circ}, \theta_{2}=30^{\circ}\right)$ を数值実験の 対象とした。

\section{(2) 計算条件}

数值実験に用いた格子は再現計算と同様の一辺 $1 \mathrm{~cm}$ の正方格子である. 粗度係数と上流端の境界条件の与 え方は再現計算と同様とした。下流端の境界条件は, 本 川に再現計算を行った際の等流水深 $h_{0}$ に基づいた水位 を与え, 支川には芦田らの水路実験の結果の流量配分 比から求められる限界水深に基づいた水位を, 本川と 支川ともに，それぞれの分岐点から $3.0 \mathrm{~m}$ 下流に与えた。 その時の水深 $h$ の変動幅は限界水深の 0.4 倍から 3.3 倍 までの間とした。この条件で定常状態に達するまで計 算を行った。

\section{(3) 計算結果}

数值実験の結果を図-6 に示す。横軸は再現計算を行つ た際の支川の下流端の水深 $h_{0}$ と数值実験で用いた下流 端の水深 $h$ の比である。その比 $h / h_{0}$ が 1.0 から離れる ほど不等流性が強く, 1.0 より小さい時には低下背水, 1.0 より大きい時には堰上げ背水の不等流である. 縦軸 は支川への流量配分比を表している。

どの流量においても流量配分比に対する下流端水深 の影響度は同程度と判断出来る。 また, 塗りつぶし記 号で示した限界水深以下の下流端水深の場合には流量 配分比はほとんど変動しないことも明らかとなった。

\section{(4) 芦田らの理論解の適用性}

不等流における芦田らの算定式の適用性の把握を試 みた。芦田らの流量配分比 $\kappa$ の算定式は以下である。

$$
\begin{gathered}
\kappa=\frac{1}{1+\Omega} \\
\Omega=\frac{B_{1}}{B_{2}} \cdot \frac{F r_{1}}{F r_{2}}\left\{\frac{F r_{2}^{2}\left(\zeta_{2}+1\right)+2}{F r_{1}^{2}\left(\zeta_{1}+1\right)+2}\right\}^{3 / 2}
\end{gathered}
$$

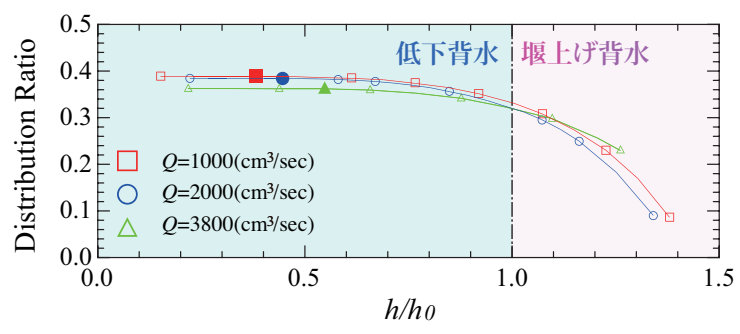

図-6 芦田らの実験水路を用いた数値実験の結果（塗りつぶし 記号は限界水深)

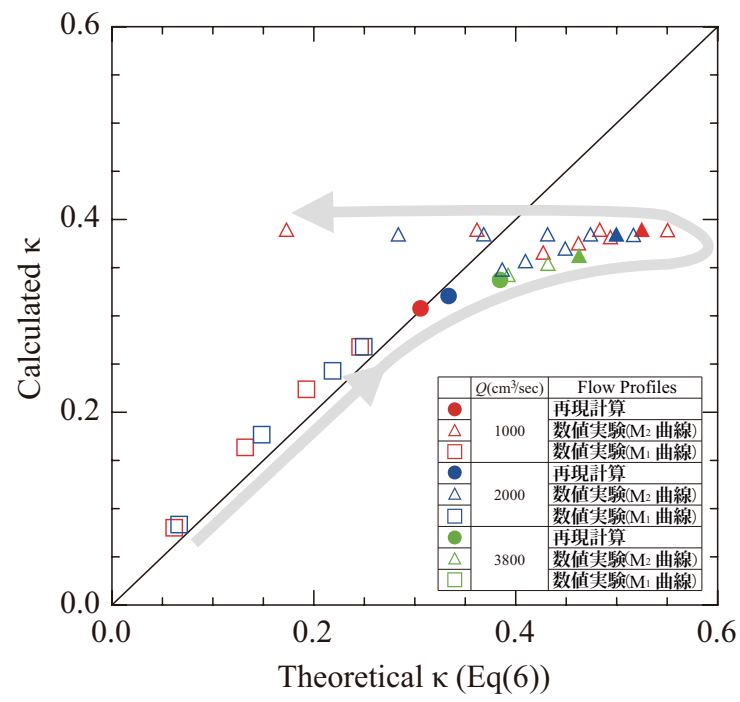

図-7 数值実験と理論的算定法の比較（塗りつぶし三角記号は 限界水深)

ここに, $B$ は水路幅, $F r$ はフルード数, $\zeta$ は断面急拡部 のエネルギー損失係数を表しており，本川および支川 を添字 $1 ， 2$ を付けて表している。この算定式は彼らの 実験水路から得られた結果のみを適用することが出来 るため, 分岐水路幅の比 $B_{1} / B_{2}$ は定数となり, フルー ド数とエネルギー損失係数を決定する分岐角度の二つ が変数となる。

彼らが示す分岐水路幅の比と流量配分比より定めら れた適用範囲外の条件でも数值実験を行ない, 流量配 分比の算定を行った.

不等流状態とした条件での数值実験より得られた流 量配分比と, 数值実験の結果から得られるフルード数 を芦田らの算定式に適用し求められた流量配分比の比 較を行った。比較の結果を図-7 に示す。

図-7 の四角で示した $\mathrm{M}_{1}$ 曲線（堰上げ曲線）におい ては, 数值実験と理論的算定法の流量配分比が概补一 致している。一方, 三角で示した $\mathrm{M}_{2}$ 曲線（低下背水曲 線）においては, 理論的算定法で求められた流量配分 比が数值実験で求められた流量配分比よりも過大に評 価されていることがわかる。

以上のことから, 芦田らの理論的算定法は $\mathrm{M}_{1}$ 曲線 においては適用可能である一方で， $\mathrm{M}_{2}$ 曲線においては 過大評価となることが明らかとなった。ここで，図に 示した矢印は数值実験に用いた水深が小さくなる方向 を表している。このことから, 芦田らの理論的算定法 


\section{表-2 数値実験条件}

\begin{tabular}{|c|c|c|c|}
\hline \multicolumn{2}{|c|}{ CASE } & $\theta_{3}\left(^{\circ}\right)$ & $Q\left(\mathrm{~cm}^{3} / \mathrm{sec}\right)$ \\
\hline \multirow{3}{*}{$\mathrm{C}$} & 1 & \multirow{3}{*}{30} & 1000 \\
\hline & 2 & & 2000 \\
\hline & 3 & & 3800 \\
\hline \multirow{3}{*}{ D } & 1 & \multirow{3}{*}{45} & 1000 \\
\hline & 2 & & 2000 \\
\hline & 3 & & 3800 \\
\hline \multirow{3}{*}{$\mathrm{E}$} & 1 & \multirow{3}{*}{60} & 1000 \\
\hline & 2 & & 2000 \\
\hline & 3 & & 3800 \\
\hline
\end{tabular}

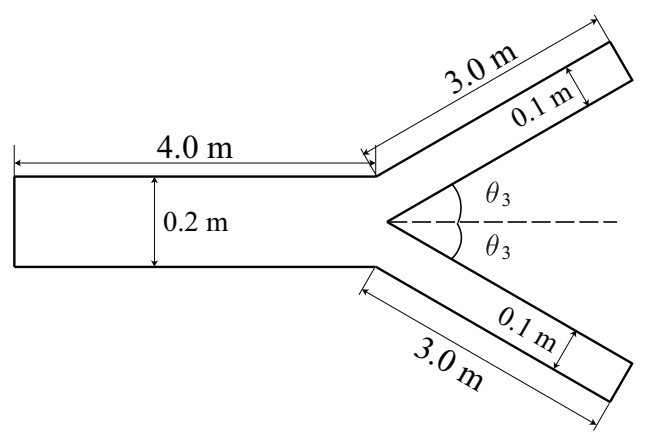

図-8 数値実験に用いた水路形状の概形

では不等流において下流端水深を独立変数として流量 配分比が連続的に変化することが分かり, 流量配分比 の推測が可能であることが示唆された.

\section{4. 分岐角度が流量配分比に及ぼす影響の把握 \\ (1) 数值実験の目的と概要}

芦田らは，実験に用いた水路形状の範囲では分岐角 度を考慮した流量配分比の算定を行った。しかし，彼 らの水路は分岐後の水路幅が本川，支川で同一でない ため，分岐角度のみの影響を個別に把握したとは言い 難い.

そこで，分岐角度のみが流量配分比に与える影響を 把握することを目的とし，分岐後のそれぞれの水路幅 を同一とした水路形状を用いて数值実験を行った。芦 田らの水路実験を参考に決定した数值実験を行う水路 の概形を図-8 に, 分岐角度, 流量の条件を表-2 に示す。

\section{(2) 計算条件}

数值実験に用いた格子は再現計算と同様に一辺 $1 \mathrm{~cm}$ の正方格子とし，水路内のみに計算格子を配置してい る. 再現計算で用いた各流量に対応する粗度係数を数 值実験にも同様に適用した。上流端の境界条件の与え 方は再現計算と同様とした。また下流端の境界条件は, 流量配分比が $50 \%$ となる時の等流水深 $h_{0}$ に基づいた水 位を一方の分岐水路に与元，もう一方の分岐水路には 流量配分比が 50\% となる時の限界水深に基づいた水位 を与えた。 その時の水深 $h$ の変動幅は限界水深から最 大で 0.4 倍から 2.8 倍とし， 0.2 倍ずつ変動させた。こ
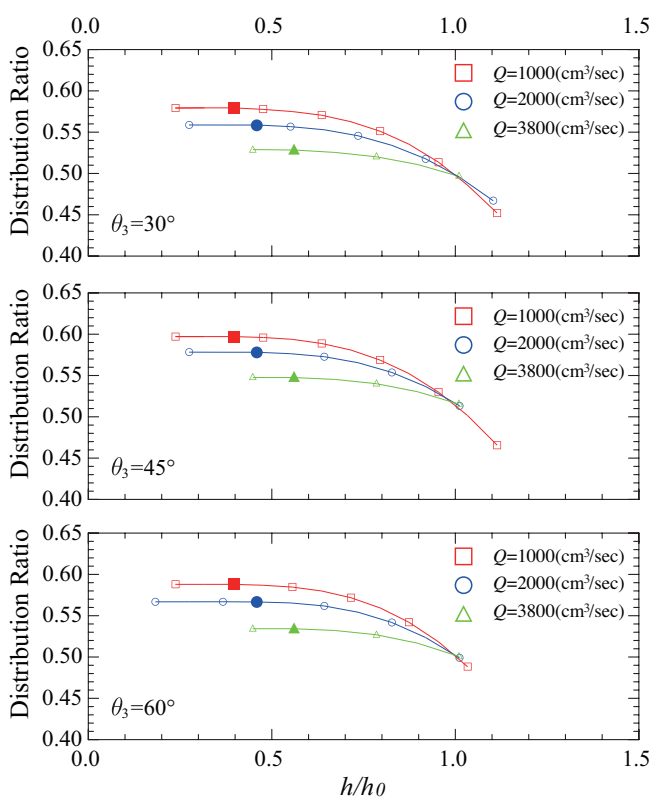

図-9 流量で比較した数值実験の結果（塗りつぶし記号は限界 水深)
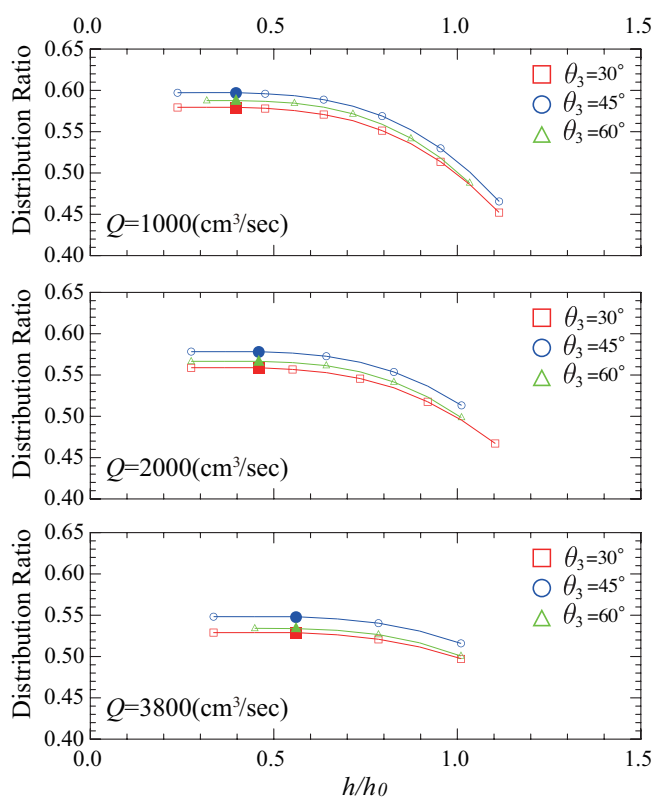

\section{図-10 分岐角度で比較した数値実験の結果（塗りつぶし記号 は限界水深)}

の条件で定常状態に達するまで計算を行った.

\section{(3) 計算結果}

数值実験の結果を分岐角度毎にまとめたものを図-9 に，流量毎にまとめたものを図-10 に示す。どちらの 図も横軸は変動させた下流端の水深 $h$ と流量配分比が $50 \%$ となる時の等流水深 $h_{0}$ の比であり, その比 $h / h_{0}$ が 1.0 から離れるほど不等流性が強いことを表している. 縦軸は下流端水深を変動させた分岐水路への流量配分 比を表している.

\section{a) 流量による流量配分比の比較}

図-9を見ると，どの分岐角度においても塗りつぶし 記号で示した限界水深よりも水深が小さい場合には流 
量配分比はほどんど変動していない．また，上流からの 流量が少ないほど流量配分比が下流端水深 $h$ の変動に 対して鋭敏に反応することが明らかとなった，上流か らの流量はフルード数とも言い換えることができ, 流 量配分比はフルード数が小さくなるほど下流端の水位 に対して鋭敏に反応するとも言える。さらに興味深い のは，フルード数に対して流量配分比が鋭敏に反応す る本数值実験の結果に対し, 図-6に示した芦田らの実 験水路における実験の結果は, ほとんどフルード数に 対して流量配分比が応答していない。これは芦田らの 実験水路において分岐水路の幅や分岐角度が同一でな かったことが原因と考元られる。

\section{b) 分岐角度による流量配分比の比較}

図-10を見ると，どの流量においても $45^{\circ} ， 60^{\circ} ， 30^{\circ}$ の順で流量配分比が大きくなる傾向がある。その傾向 は不等流性の強度に依らず維持されている。 また，同 じフルード数において角度の流量配分比への影響度が 小さいことも分かる. 以上のことから, 不等流性が及 ぼす流量配分比への影響度は分岐角度よりもフルード 数の方が大きいことが明らかとなった。

上記の二つをまとめると, 流量配分比の支配要因と して, 既往の 1 次元の理論解析が唯一の独立変数とす るフルード数だけでなく, 分岐水路の幅や分岐角度な ども密接に関係することが分かった。さらに，実河川 は平面形状が単純でないため, 一次元的な流量配分比 の算定が困難となることが分かる．

\section{5. まとめ}

本研究では，まず，芦田らの室内実験との比較によ り, 矩形格子に基づく平面 2 次元解析は分岐部の解析 において有効な手法であることを示した。二次流を無 視した水深方向に積分された平面 2 次元解析モデルで も, 水位や流量配分比の把握は可能であることが明ら かとなった。

次に，分岐水路の下流端条件を不等流とした数值実 験を実施した。その結果, 流量配分比は分岐水路幅が 同一の場合にフルード数が小さくなるほど下流端の水 位に対して鋭敏に反応することが明らかとなった。ま た，分流後を不等流状態とした数值実験の結果と，分 流後を等流と仮定して導出された芦田らの理論解を比 較したところ, 実河川に多く見られる分岐後のせき上 げ条件において有効であることが分かった，ただし，芦 田らの実験水路の形状のような単純な平面形状を有す る実河川にしか算定式を適用出来ないため，実河川へ の適用には留意が必要である。

以上のことからフルード数のみを独立変数とする一 次元的な流量配分比の算定の困難さが伺える。それに 対し, 本研究で導入した陽的な平面 2 次元解析法は, 分 岐形状を簡便かつ忠実に反映することができ，流量配分 比の算定が容易となる有効な解析手法であると言える.
謝辞 : 本研究は, 科研費基盤研究 (B)(代表者 渡邊康玄) からの支援を受けて実施されている。ここに記して謝 意を表します。

\section{参考文献}

1) Taylor, E.H.:Flow characteristics at rectangular open-channel junctions, Trans.,ASCE, Vol. 109, Paper No. 2223, pp.893902, 1944.

2) 嶋祐之, 富永正照: 射流分岐水路の流量配分比について, 土木学会論文集，第 58 号，pp.55-62，1958.

3) 室田明: 開水路分水工の研究, 土木学会論文集, 第 70 号, 別冊 $1-1,1960$.

4) 芦田和男, 川合茂: 分岐部周辺における流れの水理特性 について, 京大防災研究所年報 第 22 号 B-2, pp.491-506, 1979

5) 藤田将輝, 長谷川和義, 渡邊康立, 桑村貴志: 旧蛇行通水 時における堰の越流条件を考慮した分岐流量配分比，土 木学会北海道支部平成 14 年度（第 59 回）年次技術研究 発表会, 2002

6) 伊藤秀夫 : 低平地開水路網の定常流に関する研究, 土木学 会論文報告集，第 181 号，pp.41-53，1970.

7) 岩佐義朗, 綾史郎, 山本正幸:ネットワーク状水路の水理解 析，京大防災研究所年報，第 19 巻 B, pp.201-219, 1978.

8) 金本満, 常松芳昭: グラフ理論による河川網不定流の水理 解析, 土木学会論文集, No.429, II-15, pp.67-75, 1991.

9) 福岡捷二, 渡邊明英, 田中幸輔, 風間聡, 牛腸宏: 利根川· 江戸川分派点を含む区間における流量ハイドログラフと 粗度係数・樹木群透過係数の評価, 水工学論文集, 第 50 巻, 1165-1170, 2012.

10) Dinh,Thanh Mung, Kimura,I. Shimizu,Y.:Computation of bed deformation at a river confluence using depth-averaged 2D models, RCEM2011.

11) 後藤岳久, 福岡捷二, 田中里佳 : 太田川デル夕における 河川流路網の洪水流と河床変動に関する研究, 土木学会 論文集 B1（水工学） Vol.68, No.4, 2012.

12）原信彦，山田正：一般座標系による河川分流を考慮した高 潮・洪水同時生起の数值シミュレーション, 土木学会論文 集 B2（海岸工学）, Vol. B2-65, No.1, pp.246-250, 2009.

13) Neary, V.S. and Sotiropoulos, F. : Three-Dimensional Numerical Model of Lateral-Intake Inflows, J.Hdyraul. Eng.Vol.125, pp.126-140, 1999

14) Ramamurthy, A.S., Qu, J. and Vo, D. : Numerical and Experimental Study of Dividing Open-Channel Flows, J.Hdyraul. Eng.Vol.133, pp.1135-1144, 2007

15) 星野剛, 安田浩保, 永多朋紀 : 四分木構造格子を導入し た自然河川における分岐点と合流点の数值解法, 土木学会 論文集 B2（水工学）, Vol.68, No.4, I_853-I_858, 2012.

16) 安田浩保, 星野剛 : 四分木構造格子による局所的な高解 像度格子を導入した浅水流方程式の数值解法, 土木学会論 文集 A2（応用力学），Vol.67，No.2，I_693-I_702， 2011.

17) 永多朋紀, 安田浩保, 渡邊康玄: 2 Way 河道の自律的な維 持を可能にする分流堰高に関する検討，河川技術論文集， 第 17 巻, 2011.

18）安田浩保, 星野剛 : 一般座標の格子構成が有する打切り 誤差の理論的評価とその最適化手法, 河川流量観測の新 時代, 第 3 巻, pp.49-54, 2012.

(2012.9.30 受付) 